\title{
Effect of Dietary Supplementation of Fine Ground Corn and Soybean Oil on Ruminal Fermentation, Milk Performance, Plasma Metabolites and Oxidative Stress Parameters of Dairy Cows
}

\section{yongqing guo}

South China Agricultural University College of Animal Science https://orcid.org/0000-0002-7689-8561

\section{Bin Li}

South China Agricultural University

Yinru Han

South China Agricultural University

Ming Deng

South China Agricultural University

Guangbin Liu

South China Agricultural University

Yaokun Li

South China Agricultural University

Baoli Sun ( $\square$ baolisun@scau.edu.cn )

South China Agricultural University

Dewu Liu

South China Agricultural University

\section{Research}

Keywords: dairy cow, rumen fermentation, milk performance, plasma metabolites, oxidative stress

Posted Date: July 2nd, 2021

DOl: https://doi.org/10.21203/rs.3.rs-662036/v1

License: (c) (i) This work is licensed under a Creative Commons Attribution 4.0 International License. Read Full License 


\section{Abstract}

Background: The aim of this study was to investigate the effect of dietary supplementation of fine ground corn and soybean oil on ruminal fermentation, milk performance and fatty acid profile, plasma metabolites and oxidative stress parameters in lactating dairy cows.

Methods: Eight primiparous Holstein cows $(215 \pm 34$ d days in milk, $574.6 \pm 22.6 \mathrm{~kg}$ body weight; mean \pm SD) were allocated into 2 groups ( $n=4$ /group), used in a change-over experiment with two 23-d experimental periods ( $16 \mathrm{~d}$ induction period and $7 \mathrm{~d}$ wash-out period). During the induction period, the cows of one group were fed with control diets (CON, $23.8 \%$ starch, $4.6 \%$ fat, and $31.4 \%$ NDF, DM basis), and the cows of the second group were fed with CON diets supplementation of $266 \mathrm{~g} / \mathrm{kg}$ of fine ground corn and $46 \mathrm{~g} / \mathrm{kg}$ of soybean oil (HSO, 31.4\% starch, 7.8\% fat, and $26.4 \%$ NDF, DM basis), and all cows were fed with the CON diets during the subsequent wash-out period.

Results: The results shown that the cows fed the HSO diets had a lower ruminal molar ratio of acetate $(P$ $=0.02)$, and a numerically lower ruminal $\mathrm{pH}(P=0.13)$ and acetate : propionate ratio $(P=0.13)$ than that in the cows fed the CON diets. Cows fed the HSO dites had a lower $(P<0.05)$ dry matter intake (DMI), milk yield, milk fat percentage, the yield of milk fat, protein and solid of non-fat (SNF), and a higher $(P<0.05)$ percentage of milk protein, lactose and SNF than that in the cows fed with CON diets. Cows fed the HSO diets had a lower $(P<0.05)$ concentrations $[\mathrm{g} / 100 \mathrm{~g}$ total FA] of C8:0, C10:0, C11:0, C12:0, C14:0, $\mathrm{C} 15: 0, \mathrm{C} 16: 0, \mathrm{C17}: 0, \mathrm{C} 18: 0$, fatty acids $(\mathrm{FA})<\mathrm{C} 16$, sum of $\mathrm{C} 16: 0$ and $\mathrm{C} 16: 1$, total saturates $\mathrm{FA}$, and medium chain FA, and a greater $(P<0.05)$ milk concentrations of C14:1, C16:1, C18:1n9t, C18:2n6t, $\mathrm{C} 18: 2 \mathrm{n} 6 \mathrm{c}, \mathrm{C} 18: 3 \mathrm{n} 3, \mathrm{FA}>\mathrm{C} 16$, total unsaturated FA, total mono-unsaturated FA, total poly-unsaturated FA, $\triangle 9$-desaturase index, than that in the cows fed the CON diet. Compared with the cows fed the CON diet, the concentrations of plasma non-esterified fatty acids (NEFA), aspartate aminotransferase (AST), malondialdehyde (MDA) increased $(P<0.01)$, whereas the concentrations of the $\beta$-hydroxybutyrate (BHBA), urea nitrogen (BUN), alanine aminotransferase (ALT), albumin (ALB), total antioxidant capacity (T-AOC), the ratio of ALB to GLB, the activity of superoxide dismutase (SOD) and glutathione peroxidase (GSH-Px) decreased $(P<0.05)$ in cows fed the HSO diets.

Conclusions: Our results indicate that HSO diets can impact on the ruminal fermentation pattern, reduce the DMI, milk fat content, depress the de novo synthesis of lipid in mammary gland, disturb plasma parameters, enhance the oxidative stress in dairy cows. Meanwhile, we also found the the subacute rumen acidosis (SARA) and milk fat depression (MFD) can occur at the same time or one after the other, when dairy cows fed with HSO diets.

\section{Background}

The productivity of dairy cows has increased greatly over the last few years. However, the nutrient management challenge become more serious with milk yield increases in high-producing dairy cows. Currently, feeding high-concentrate diets become a common practice in many dairy farms throughout the 
world[1]. In order to meet the high energy requirements of high-yielding dairy cows, which are often fed with energy-dense feeds, such as cereal grain, whole corn silage, cottonseed, extruded full-fat soybean or high-fat by-products, resulting in the fermentable carbohydrates or polyunsaturated fatty acids (PUFA) content increased in the diet, as resulted in increase the risk of subacute rumen acidosis (SARA) or milk fat depression (MFD) [2]. The higher rapidly fermentable carbohydrates in diets can impaire the digesta stratification and providing fewer stimuli for chewing, reducing salivary buffer supply, resulted in long and frequent ruminal $\mathrm{pH}$ depression [3], which termed as SARA. It is agreed that SARA occurs when the ruminal $\mathrm{pH}$ is lower than 5.5-5.8 for several hours per day [4]. MFD is a disorder characterized by a reduction in milk fat content and yield, which attributed to reduced mammary capacity for lipid synthesis caused by the formation of specific biohydrogenation intermediates in the rumen [5]. SARA and MFD are two prime example of the interaction of diet and rumen microflora resulting in a change in body metabolism.

MFD can be induced by a large amount of unsaturated FA [6] or high fermentable carbohydrates [7] in the diets of dairy cows, although many other dietary factors, such as feed particle size [8] and NDF level [9], may interact to the milk fat synthesis. Moreover, high fermentable carbohydrates diets also can decrease the rumen $\mathrm{pH}, \mathrm{DMI}$, fiber digestibility, plasma plasma antioxidant capacity, and increase the flow of transFA from the rumen to mammary gland, resulting in increase the risk of SARA or MFD in dairy cows $[10,11]$. Variation in diet fermentability and fat content are regular occurrence on commercial dairy farms, due to the changes in moisture concentration and composition of feed ingredients, mixing errors of total mixed ration (TMR), sorting of TMR by cows, and other factors [12]. This diet variation can impair the rumen and body health, and resulted in decrease the milk content, yield and efficiency of dairy cows.

In previous research, high fermentable carbohydrates diet was usually used to induce SARA [13], and high unsaturated fatty acid diet was used to induce MFD in dairy cows [14]. However, the energy-dense diets may include higher fermentable carbohydrates and unsaturated fatty acid together. Therefore, the current study was designed to investigate the dietary supplementation of fine ground corn and soybean oil on ruminal fermentation, milk performance, plasma metabolites and oxidative stress parameters of lactating dairy cows. We hypothesized that the fed with the high-fermentable carbohydrates and unsaturated fatty acid diets can reduce the ruminal $\mathrm{pH}$ and milk fat content simultaneously in dairy cows.

\section{Materials And Methods}

\section{Experimental design and animal management}

Eight healthy, primiparous Holstein cows ( $215 \pm 34$ d days in milk, $574.6 \pm 22.6 \mathrm{~kg}$ body weight; mean \pm SD) were allocated into 2 groups ( $n=4 /$ group), used in a two-period, two-treatment crossover design, each period was $23 \mathrm{~d}$ in duration, including $16 \mathrm{~d}$ induction period (12 days for adaptation and 4 days for sample collecting) and $7 \mathrm{~d}$ wash-out period. During the each induction period, the cows of one group were fed with control diets (CON: $23.8 \%$ starch, $4.6 \%$ fat, and $31.4 \%$ NDF, DM basis) , and the cows of the second group were fed with high-starch and high-oil diets (HSO, 31.43\% starch, $7.80 \%$ fat, and $26.42 \%$ 
NDF, DM basis), using CON diets supplementation of $266 \mathrm{~g} / \mathrm{kg}$ of fine ground corn (passing through 1.5 $\mathrm{mm}$ sieve mesh size) and $46 \mathrm{~g} / \mathrm{kg}$ of soybean oil (DM basis). During the subsequent wash-out period, all cows were fed with the CON diets. The two diets (Table 1) were formulated to meet or exceed the NRC [15] guidelines for $600 \mathrm{~kg}$ primiparous Holstein dairy cows producing $30 \mathrm{~kg}$ of milk/d with $4.0 \%$ fat. The diets were fed as a total mixed ration (TMR) (CAU-mixer wagon model JZC-200, Beijing, China), and the forage component of the diet was a mixture of corn silage, chopped alfalfa hay, and oat hay. The moisture content of corn silage was determined weekly and used to adjust the ration.

The experiment was conducted from November to December at the dairy farm of the Huamei (Guangzhou, China). The cows were housed in individual tie-stalls bedded with sawdust and rubber mattresses, and had free access to drinking water throughout the trial. They were fed twice daily, in equal amounts, at 0700 and $1700 \mathrm{~h}$. The diets were fed ad libitum to allow for at least $5-10 \%$ orts on an as-fed basis.

\section{Feed sampling and analysis}

During d13 - d15 of each induction period, the diets and ort samples of individual cows were harvested daily to calculate dry matter intake (DMI). The daily diets and orts were pooled by dietary treatment and cows, and stored at $-20^{\circ} \mathrm{C}$ until analysis. After the experiment, all the samples were dried in a forced-air oven (Yiheng, Model DHG-9240A, Shanghai, China) for $72 \mathrm{~h}$ at $65^{\circ} \mathrm{C}$, and ground in a Wiley mill through 1mm screen (standard model 4; A. H. Thomas, Philadelphia). Samples of diets were composited by period and analyzed for ash, dry matter (DM), crude protein(CP) and ether extract by wet chemistry procedures according to AOAC [16], and for NDF and ADF according to Van Soest et al. [17], and for starch according to Bal et al. [18]. The chemical composition of the TMR was calculated from the chemical composition of the concentrate mix and the individual forage in the diets. FA in diet were determined by gas chromatography(7980; Agilent Technologies Inc, Santa Clara, CA) [19]. The diets of HSO had a higher content of starch and fat, and a lower content of NDF and CP than the CON diets.

\section{Rumen samples collection and fermentation parameters}

Ruminal samples were collected for $\mathrm{pH}$, volatile fatty acids (VFA) and $\mathrm{NH}_{3}-\mathrm{N}$ analysis. Rumen fluid samples $(200-300 \mathrm{~mL})$ were collected from the all cows using an oral stomach probe [20] at 3-4h after morning feeding on the $15 \mathrm{~d}$ of each induction period. The supernatant was immediately measured for $\mathrm{pH}$ using a hand-held pH electrode (Model pH B-4; Shanghai Chemical, Shanghai, China), put on ice, and stored at $-20^{\circ} \mathrm{C}$. These samples were later analyzed for $\mathrm{NH}_{3}-\mathrm{N}$ using the phenol-hypochlorite procedure [21] and for VFA [22]. The concentration of $\mathrm{NH}_{3}-\mathrm{N}$ was determined on a UV-Vis spectrophotometer (UV-2600, Unocal instruments Co., Ltd., Shanghai, China) by colorimetry; and the concentrations of VFAs were determined by gas chromatography (SP-3420, Beijing analytical instrument factory, Beijing, China).

\section{Milk performance and fatty acid profile}


Cows were milked twice per day at 0630 and $1630 \mathrm{~h}$ and milk yields were determined by an integrated milk meter (MM25; DeLaval International, Tumba, Sweden). Milk was sampled at both milkings from 13d to $15 \mathrm{~d}$ of the induction period. Milk sample was stored at $4^{\circ} \mathrm{C}$ and analyzed for fat, protein, lactose, and SNF by infrared spectroscopy (LactoStar 3560; FUNKE GERBER, Berlin, Germany).

The methylated FA of the milk were analysed on an Agilent 7980 gas chromatograph (Agilent Technologies Inc, Santa Clara, CA, USA $)$ with an CP Sil $88(60 \mathrm{~m} \times 0.25 \mathrm{~mm} \times 0.20 \mu \mathrm{m}$; Agilent Technologies Inc, Santa Clara, CA, USA) column for FA methyl esters. For milk FA analysis, frozen milk samples from individual cows were thawed in a refrigerator at $4^{\circ} \mathrm{C}$; morning and evening samples were pooled together (50:50 vol/vol) before milk FA analysis. Extraction, methylation and separation of the FA were performed as described by previous reports in the literature [23]. The FA were reported as $\mathrm{g} / 100 \mathrm{~g}$ of FA methyl esters (FAME).

\section{Blood samples collection and analysis}

On d 15 of each period, $10 \mathrm{ml}$ of blood samples of all cows were collected, via tail venipuncture before morning feeding (Oh), into vacutainer tubes (Becton Dickinson, Franklin Lakes, NJ, USA) containing sodium heparin anticoagulant. Plasma was collected after centrifugation at $3,000 \mathrm{~g}$ for $10 \mathrm{~min}$, separated into several aliquots, frozen at $-20^{\circ} \mathrm{C}$. The contents of nonesterified fatty acid (NEFA), glucose (Glu), total cholesterol (TC), triglyceride (TG), urea nitrogen (BUN), alanine aminotransferase (ALT), aspartate aminotransferase (AST), alkaline phosphatase (ALP), total protein (TP) and albumin (ALB) in plasma using commercial kits (Biosino Bio-Technology \& Science Inc., Beijing, China) by Beijing North Biotechnology Research Institute (Beijing, China) with a Hitachi 17080 Automatic Biochemical Analyzer (Hitachi Co., Ltd., Japan). The plasma insulin levels were determined using an insulin radioimmunoassay kit (Beijing North Institute of Biological Technology, Beijing, China) with a multi tube radioimmunoassay (DFM-96; Hefei Zhongcheng Electromechanical Technology Co., Ltd, Hefei, China) according to the manufacturer's instructions. $\beta$-Hydroxybutyric acid (BHBA) dehydrogenase was used for quantifying the plasma concentration of BHBA using a Beckman Coulter AU5821 automatic biochemical analyzer (Beckman Coulter, Brea, CA, USA). Total antioxidant capacity (T-AOC), superoxide dismutase (SOD), glutathione peroxidase (GSH-Px), catalase (CAT) and malondialdehyde (MDA) in plasma were measured by colorimetric assay kits (Nanjing Jiancheng Bioengineering Institute, Jiangsu, China) with microplate reader (DG5033A; Huadong Electronics Group Medical Equipment Co, Ltd).

\section{Statistical analysis}

Data on ruminal fermentation parameters, milk performance, milk fatty acid, and plasma metabolites were analyzed using the PROC MIXED of SAS (version 9.4; SAS Institute Inc., Cary, NC) based on the following model:

$Y_{i j k l}=\mu+S_{i}+T_{j}+N_{k(S i)}+P_{1}+E_{i j k l}$ 
where $Y_{i j k m}=$ dependent variable, $\mu=$ overall mean, $S_{i}=$ random effect of sequence $(i=1$ to 2$), T_{j}=$ effect of treatment diet ( $\mathrm{j}=1$ to 2$), \mathrm{Nk}_{(\mathrm{Si})}=$ random effect of cow nested in sequence ( $k=1$ to 8$), \mathrm{P}_{\mathrm{l}}=$ random effect of period ( $\mathrm{I}=1$ to 2$), \mathrm{E}_{\mathrm{ijkl}}=$ residual error. The Kenward-Rogers denominator degrees of freedom method was used to account for unequal variances. Data points with Studentized residuals outside of \pm 3.0 were considered outliers and excluded from analysis. Effects were compared by using the Tukey's range test, and differences were considered significant at $P \otimes 0.05$ or as a tendency at $P \otimes 0.10$.

\section{Results}

\section{Rumen $\mathrm{pH}$ and fermentation parameters}

As shown in table 2, the cows fed the HSO diets had a lower ruminal molar ratio of acetate $(P=0.02)$ and concentration of $\mathrm{NH}_{3}-\mathrm{N}(P<0.01)$ than that in the cows fed the $\mathrm{CON}$ diets. The ruminal $\mathrm{pH}$ and the ratio of acetate to propionate of cows fed the HSO diets was numerically lower $(P=0.13)$ than that in the cows fed the CON diets, but the difference did not reach statistical signiticance. The total VFA, the concentrations of individual VFA, the relative molar proportions of propionate and butyrate were not affected by diets.

\section{DMI, milk production and composition}

In the current study, feeding HSO diets decreased $(P<0.01)$ fat-corrected milk (FCM), milk fat percentage, and fat yield compared with the CON diets (Table 3). Moreover, the cows fed the HSO dites had a lower $(P<0.05)$ DMl, milk yield, energy-corrected milk (ECM), FCM/DMI, protein yield and solid of non-fat (SNF) yield, and a higher $(P<0.05)$ percentage of milk protein, lactose and SNF than that in the cows fed with the CON diets.

\section{Milk fatty acid profile}

Cows fed the HSO diets had a lower $(P<0.05)$ concentrations of C8:0, C10:0, C11:0, C12:0, C14:0, C15:0, $\mathrm{C} 16: 0, \mathrm{C} 17: 0, \mathrm{C} 18: 0, \mathrm{FA}<\mathrm{C} 16$, sum of $\mathrm{C} 16: 0$ and $\mathrm{C} 16: 1$,total saturates $\mathrm{FA}$, and medium chain $\mathrm{FA}$, and a greater $(P<0.05)$ milk concentrations [g/100 g total FA] of C14:1, C16:1, C18:1n9t, C18:2n6t, C18:2n6c, $\mathrm{C} 18: 3 \mathrm{n} 3, \mathrm{FA}>\mathrm{C} 16$, total unsaturated FA, total mono-unsaturated FA, total poly-unsaturated FA, $\Delta$ 9desaturase index, compared with the cows fed the CON diet (Table 4). There were no significant differences in milk concentrations of $\mathrm{C} 6: 0$ and $\mathrm{C} 18: 1 \mathrm{n} 9 \mathrm{c}$ between two dietary treatments.

\section{Plasma metabolites and oxidative stress parameters}

Compared with the cows fed the CON diet, cows fed the HSO diets had a higher concentrations of plasma NEFA $(P<0.01)$ and AST $(P<0.01)$, and a lower concentrations of the BHBA $(P=0.05)$, BUN $(P<$ $0.01)$, ALT $(P<0.01)$, ALB $(P=0.02)$, and the ratio of ALB to GLB $(P=0.02)$ (Table 5). ALP concentrations tended to increase $(P=0.06)$ when cows were fed with HSO diets. There were no significant differences in plasma concentrations of glucose, TC, TG, Insulin, TP, and GLB between two dietary treatments. 
Cows fed with the HSO diets had a higher plasma concentrations of MDA $(P=0.02)$, and a lower concentrations of T-AOC $(P=0.01)$, the activity of SOD $(P=0.01)$ and GSH-Px $(P=0.03)$, compared with the cows fed the CON diet (Table 6). However, the activity of CAT was not affected by dietary treatments.

\section{Discussion}

\section{Rumen $\mathrm{pH}$ and fermentation parameters}

Rumen $\mathrm{pH}$ and VFA composition are the basic indexes to evaluate rumen fermentation activity of dairy cows, it is mainly affected by animal saliva, buffer system, diet composition and degradation rate, which are closely related to the utilization rate of fermentation substrate by rumen microorganisms[24]. In current study, the cows fed with the HSO diets resulted in a lower rumianl molar ratio of acetate, and numerically decreased in the ruminal $\mathrm{pH}$ and the ratio of acetate to propionate. A previous study reported that a large mount of fermentable starch in the diets can increase the VFA production and reduce $\mathrm{pH}$ in the rumen, which could increase the risk of SARA [25]. However, supplement of plant oil in diet of cows fed with the high-concentrate diets could increase the rumen $\mathrm{pH}$, compared to the cows fed with the low-concentrate diets [26], which is in consistent with our study, the rumen $\mathrm{pH}$ relatively less affected by cows fed with the diet including high amount fermentable starch and plant oil at the same time. The HSO diets reduced the molar acetate and the acetate to propionate ratio in rumen VFA, consistent with the previous studies[26, 27], which can be attributed to the HSO diet can inhibit the ruminal cellulase activity and fiber degradation [28], and the lower NDF level in HSO diet. Consistent with our results, Zened et al. [29] also showed that the cows fed with HSO diets had a similar rumen $\mathrm{pH}$ pattern and low acetate to propionate ratio. In this study, cows fed the HSO diets had a lower concentration of $\mathrm{NH}_{3}-\mathrm{N}$ than that in the cows fed the CON diets, the main reason for this difference could be the lower proportion of silage and protein ingredients in HSO diet. In addition, adding starch in diets would be expected to facilitate better utilization of $\mathrm{NH}_{3}-\mathrm{N}$ and reduce the deamination of amino acids by rumen microorganisms [30].

\section{DMI, milk production and composition}

High fermentable carbohydrate diets containing high amounts of PUFA typically cause MFD in lactating cows. As designed and expected, diet supplementation with fine ground corn and soybean oil caused MFD, which was characterized by a significant lower milk fat concentration (from $4.07 \%$ to $2.83 \%$ ) compared to that of the CON diet, a result similar to that of previous research studies [32, 31]. The HSO diet include more fermentable carbohydrate and PUFA, resulting in alter bacterial metabolism in the rumen, leading to the formation of CLA isomers that downregulate milk fat synthesis in the mammary gland[5].

As mentioned before, diet-induced MFD is characterized by a reduction of milk fat and no other milk components are affected [33]. However, in this study, we found that the yield of milk, FCM, ECM, and SNF were decreased, whereas the percentage of milk protein, lactose and SNF were increased when cows fed the HSO diets. The lower milk yield, FCM and ECM can be explained by the reduced DMI when cows 
fed the HSO diets. The reduction in DMI was consistent with the increased fermentable carbohydrate and PUFA content in diets[34], consistent with some [35, 7], but not all studies [36, 32]. Harvatine and

Allen [37] reported that the reduced the DMI due to the PUFA intake of cows, and a greater DMI depression would be expected to make up for the large reduction in energy required for milk fat synthesis. Harvatine et al. [5] indicated that cows under MFD may experience an energy-saving effect, which can redistribute energy toward body reserve storage, as a result of reduced milk energy output. In this study, the percentage of milk protein was higher in cows fed with the HSO diet, which similar to the results of Ventto et al.[14], who indicated that the milk protein percentage increased when cows were fed high starch diet. Synchronising the ruminal fermentability of starch and protein sources can increases the outflow of bacterial protein from the rumen [38], which indicated that an proper amount of fermentable starch in diet may improve the efficiency of $\mathrm{N}$ utilisation. Normally, the milk lactose percentage is low variability than the fat and protein percentage. In this study, we found that the HSO treatment had a higher milk lactose percentage than the $\mathrm{CON}$ treatment, mainly becasuse the cows fed with high concentrate or high-energy diet can improve the milk lactose synthesis [39].

\section{Milk fatty acid profile}

The measurement of milk FA profiles can evaluate the dietary effects on rumen biohydrogenation of FA and provide a qualitative description of the rumen microbial population [40]. In this study, HSO diet had a great effect on the milk FA composition. Inclusion of unsaturated fat in diets can inhibit the de novo synthesis of short- and medium-chain FA and increases the concentration of C18 FA, resulting in a more unsaturated milk fat in dairy cows and goat [41]. We also found that the short- and medium-chain FA were reduced, where as unsaturated FA were increased by cows fed the HSO diet. Due to the fact that all the FA<C16 in milk is produced via de novo synthesis [42], the lower of C8:0, C10:0, C11:0, C12:0, C14:0, C15:0 means that the HSO diet can depress the de novo synthesis of lipid in mammary gland.

An decrease concentrations of milk C11:0 and C15:0 FA in dairy cows fed with the HSO diets could be attributed to the synthesis of odd-chain FA de novo from ruminal propionate by the mammary gland [43]. Odd- and branched-chain FA mainly originate from microbial fermentation products in the rumen, and feeding plant oil to dairy cows induces changes in the rumen microbial population that can result in a lower outflow of these FA [44]. Becaues of all the milk C14:0 FA is produced via de novo synthesis in the mammary gland, desaturation is the only origin of $\mathrm{C} 14: 1$, therefore the $\Delta 9$-desaturase index is the best indicator of $\Delta 9$-desaturase activity. In this study, the higher $\Delta 9$-desaturase index indicate that the HSO diet had a positive effect on $\Delta$ 9-desaturase activity. As a result, the mono-unsaturated FA (C14:1, C16:1) increased in HSO treatment, which is similar to the reported of Enjalbert et al. [45] who fed the cows with high starch diets.

The increased of milk C18:1n9t, C18:2n6t, C18:2n6c, C18:3n3 and total unsaturated FA of cows fed the HSO diets is closely linked to incomplete biohydrogenation of PUFA in the rumen [46]. As report prvious, supplementation with higher PUFA diets to dairy cows resulted in a lower rumen concentrations of saturated FA and a higher concentrations of MUFA and PUFA [47], resulting in a higher percentage of UFA 
to SFA in milk fat $[48,49]$. The increased in UFA, such as eicosapntemacnioc acid (EPA), docosa hexaenoic acid (DHA) and 18:3n-3FA, might be positive to beneficially affect human health[50].

\section{Plasma metabolites and oxidative stress parameters}

The contents of NEFA and BHBA in plasma were usually used as a marker of energy balance in dairy cows [51]. In this study, the cows fed with the HSO diets had a higher concentration of NEFA, and a lower concentration of BHBA than fed with the CON diets, whereas the concentration of glucose, TC, TG, insulin did not affected by dietary treatment. The results of this study has been reveal that HOS diet had a significant effect on diurnal fluctuations in plasma metabolites, and can inhibit the de novo synthesis or uptake of FA, or reduce the intracellular re-esterification of FA released by lipolysis [52]. The plasma BHBA was original from absorbed butyrate or from the NEFA oxidation in hepatic tissue [53]. The lower concentration of plasma BHBA was probably due to the variation of its sources and the higher energy density of the HSO diets. Similar to our results, Roche et al. [54] also found that the increase of dietary non fibrous carbohydrate (NFC) level would increase the plasma concentration of NEFA and glucose, and decrease concentration of BHBA. There are also different results, dietary supplementation with $1.5 \%$ soybean oil or $3.0 \%$ soybean oil significantly increased the serum glucose and insulin concentrations, and decreased NEFA and BHBA concentration [55]. BUN is the major end product of $\mathrm{N}$ metabolism in dairy cows, and high concentrations of BUN means an inefficient utilization of dietary N [56]. In this study, we found that the cows fed with the HSO diets had a lower concentrations of the BUN, which indicates that a lower amount of $\mathrm{NH}_{3}$ was released in the rumen after feeding, and lower than the capacity of microbes to utilize it, which may be related to the lower DMI and dietary CP level of HSO treatment. Previous researchers have demonstrated that the urea nitrogen in milk or blood is more closely related to the changes in dietary CP level than the ratio of dietary CP to energy intake, efficiency of $\mathrm{N}$ utilization, or rumen ammonia concentration [57].

Plasma AST and ALT are important transaminases in animals, and are considered as important indicators of liver injury [58]. The hepatic cells consist of higher concentrations of AST and ALT in cytoplasm, when the liver has acute or chronic disease, the permeability of hepatocyte membrane increasesd, and the AST and ALT in cytoplasm are released into the bloodstream, resulting in the increase of the activity of AST and ALT in the blood [59].The results of this study has been showed that the cows fed with the HSO diets had a higher activity of AST and a lower activity of ALT, and the AST / ALT > 1, which indicated that the HSO diets has potential damage to the liver of dairy cows. ALB and GLB were always used as indicators of the liver capacity for protein synthesis. The concentration of ALB and the ratio of ALB to GLB significantly decreased in cows fed the HSO diets in this study, which indicated that there might be a reduction in the capacity of the liver for protein synthesis.

Oxidative stress is a promoting factor to depress the immune function and to increase the susceptibility of disease in dairy cows [60]. Lipid peroxidation (MDA) in blood can used for the evaluation of oxidative stress severity [61]. T-AOC in blood is a comprehensive indicator that aims to describe the dynamic equilibrium between prooxidants and antioxidants. In the present study, cows fed the HSO diets had 
increased concentrations of plasma MDA, and decreased concentrations of T-AOC. It is suggested that cows fed HSO diets were more susceptible to oxidative stress than the CON diets, which in corroboration with the previous reports $[63,11]$, and they demonstrated that cows fed with high grain diets had a higher concentrations of MDA and lower concentrations of T-AOC than that in the control diets. Moreover, high fat diet can induce lipoperoxidation [64] and to increase cytochrome P450 activity [65], which is involved in fatty acid oxidation. Hence, it resulted to stimulate the production of endogenous reactive oxygen species. Diets rich in readily available carbohydrates [66] and unsaturated fatty acid [67] can adversely affect rumen metabolism, which is related to an increase in the production of harmful and toxic substances or reduce the growth of cellulolytic bacteria in the rumen, and potentially causes immune suppression and metabolic changes in dairy cows.

SOD and GSH-PX are important antioxidant enzymes in blood, which can remove excess free radicals, reduce the production of reactive oxygen species (ROS), prevent oxidative stress, and repair oxidative damage caused by oxidative stress [68]. In this study, cows fed the HSO diets had a lower activity of SOD and GSH-Px than fed the CON diet, which indicated that the HSO diets can reduce the antioxidant capacity and increase the oxidative stress of dairy cows. This finding is in accordance with a previous report from Pi et al. [69], who suggested that diet supplementation with rubber seed oil and flaxseed oil had a lower activity of CSH-Px in serum than that in cotrol group, whereas the SOD activity not affected dy dietary treatment.

\section{Conclusions}

In conclusion, dietary supplementation of fine ground corn and soybean oil resulted in a lower ruminal molar ratio of acetate, DMI, milk fat content, milk short- and medium-chain FA, disturb plasma parameters, and reduced the plasma antioxidant capacity in dairy cows. Moreover, we also found that the SARA and MFD can occur at the same time or one after the other, when dairy cows fed with HSO diets. Our results suggested that a high dietary fermentable carbohydrates and unsaturated fatty acid has a negative impact on milk fat synthesis and antioxidant capacity in dairy cows, which helps us how to adjust the feeding strategy to use energy-rich diets more effectively.

\section{Declarations}

\section{Acknowledgements}

The authors gratefully thank all the staff in Hua Mei Dairy Farm (Guangzhou, China) for their assistance in feeding, milking and care of the cows.

\section{Authors' contributions}

YQG, BLS and DWL designed the research; BL,YRH and MD performed the research; YQG, BL and YRH conducted data analysis and prepared the initial draft; DWL developed the overall concept, gave scientific guidance throughout the research, and aided in editing of the manuscript and critical analysis; GBL,YKL 
and BLS conducted critical analysis. All authors critically revised the manuscript and gave final approval for submission.

\section{Funding}

This research was supported by National Nature Science Foundation of China (31501982 and 31872382) and Natural Science Foundation of Guangdong Province (201981515210020).

\section{Availability of data and materials}

The authors confirm that all data underlying the findings are fully available without restriction.

\section{Ethics approval and consent to participate}

The experimental design and procedure presented in this study were reviewed and approved by the Animal Care and Use Committee of the South China Agricultural University, Guangzhou, China (approval number SCAU\#2013-10).

\section{Consent for publication}

Not applicable.

\section{Competing interests}

The authors declare that they have no competing interests.

\section{Author details}

${ }^{1}$ Guangdong Laboratory of Modern Agricultural Science and Technology in Lingnan, South China Agricultural University, Guangzhou 510642,China. ${ }^{2}$ College of Animal Science, South China Agricultural University, Guangzhou 510642, China.

\section{References}

1. Zhang R, Zhu W, Mao S. High-concentrate feeding upregulates the expression of inflammationrelated genes in the ruminal epithelium of dairy cattle. J Anim Sci Biotechno. 2016;7(1): 1-13.

2. Bauman DE, Griinari JM. Nutritional regulation of milk fat synthesis. Annu Rev Nutr. 2003;23(1): 20327.

3. Humer E, Aschenbach JR, Neubauer V, Kröger I, Khiaosa Ard R, Baumgartner W et al. Signals for identifying cows at risk of subacute ruminal acidosis in dairy veterinary practice. $\mathrm{J}$ Anim Physiol an $\mathrm{N}$. 2018;102(2): 380-92. 
4. Tajik J, Nazifi S. Diagnosis of subacute ruminai acidosis: A review. Asian Journal of Animal Sciences. 2011;5(2): 80-90.

5. Harvatine KJ, Boisclair YR, Bauman DE. Recent advances in the regulation of milk fat synthesis. Animal An International Journal of Animal Bioscience. 2009;3(01): 40-54.

6. Kairenius $\mathrm{P}$, Leskinen $\mathrm{H}$, Toivonen V, Muetzel S, Ahvenjärvi S, Vanhatalo A et al. Effect of dietary fish oil supplements alone or in combination with sunflower and linseed oil on ruminal lipid metabolism and bacterial populations in lactating cows. J Dairy Sci. 2018;101(4): 3021-35.

7. Longuski RA, Ying Y, Allen MS. Yeast culture supplementation prevented milk fat depression by a short-term dietary challenge with fermentable starch. J Dairy Sci. 2009;92(1): 160-7.

8. Grant RJ, Colenbrander VF, Mertens DR. Milk fat depression in dairy cows: Role of particle size of alfalfa hay. J Dairy Sci. 1990;73(7): 1823-33.

9. Rico DE, Harvatine KJ. Induction of and recovery from milk fat depression occurs progressively in dairy cows switched between diets that differ in fiber and oil concentration. J Dairy Sci. 2013;96(10): 6621-30.

10. Bradford BJ, Allen MS. Milk fat responses to a change in diet fermentability vary by production level in dairy cattle. J Dairy Sci. 2004;87(11): 3800-7.

11. Guo Y, Xu X, Zou Y, Yang Z, Li S, Cao Z. Changes in feed intake, nutrient digestion, plasma metabolites, and oxidative stress parameters in dairy cows with subacute ruminal acidosis and its regulation with pelleted beet pulp. J Anim Sci Biotechno. 2013;4: 1-10.

12. Stone WC. Nutritional approaches to minimize subacute ruminal acidosis and laminitis in dairy cattle. J Dairy Sci. 2004;87: 13-26.

13. AlZahal O, Dionissopoulos L, Laarman AH, Walker N, McBride BW. Active dry< $i>$ Saccharomyces cerevisiae can alleviate the effect of subacute ruminal acidosis in lactating dairy cows. J Dairy Sci. 2014;97(12): 7751-63.

14. Ventto L, Leskinen $H$, Kairenius P, Stefański T, Bayat AR, Vilkki J et al. Diet-induced milk fat depression is associated with alterations in ruminal biohydrogenation pathways and formation of novel fatty acid intermediates in lactating cows. Brit J Nutr. 2017;117(3): 364-76.

15. NRC. 2001. Nutrient requirements of dairy cattle No. 1, 7th ed $₫$ Washington D.C.: National Academy Press.

16. AOAC. Official methods of Analysis of the AOAC. Volume 2. Association of Official Analytical Chemists Inc.; 1990. 
17. Van Soest PJ, Russell Mcdowell L, Chesworth J, Tawes RW, Siebert SF, Orskov ER. Nutritional ecology of the ruminant. Cornell University P. 1994;44(11): 2552-61.

18. Bal MA, Shaver RD, Jirovec AG, Shinners KJ, Coors JG. Crop processing and chop length of corn silage: Effects on intake, digestion, and milk production by dairy cows. J Dairy Sci. 2000;83(6): 1264-73.

19. Sukhija PS, Palmquist DL. Rapid method for determination of total fatty acid content and composition of feedstuffs and feces. J Agr Food Chem. 1988;36(6): 1202-6.

20. Shen JS, Chai Z, Song LJ, Liu JX, Wu YM. Insertion depth of oral stomach tubes may affect the fermentation parameters of ruminal fluid collected in dairy cows. J Dairy Sci. 2012;95(10): 5978-84.

21. Broderick GA, Kang JH. Automated simultaneous determination of ammonia and total amino acids in ruminal fluid and in vitro media. J Dairy Sci. 1980;63(1): 64-75.

22. Cao ZJ, Li SL, Xing JJ, Ma M, Wang LL. Effects of maize grain and lucerne particle size on ruminal fermentation, digestibility and performance of cows in midlactation. J Anim Physiol an N. 2008;92(2): 157-67.

23. Liang $Y$, Wang $Y$, Yang $B$, ZHANG S. Analysis of $c 9$, $t 11$-conjugated linoleic acid in milk by gas chromatography. China Dairy Industry. 2006;34(7): 56-60.

24. Krehbiel CR. Invited Review: Applied nutrition of ruminants: Fermentation and digestive physiology. The Professional Animal Scientist. 2014;30(2): 129-39.

25. Enemark J. The monitoring, prevention and treatment of sub-acute ruminal acidosis (SARA): A review. The Veterinary Journal. 2008;176(1): 32-43.

26. Bayat AR, Ventto L, Kairenius P, Stefański T, Leskinen $H$, Tapio I et al. Dietary forage to concentrate ratio and sunflower oil supplement alter rumen fermentation, ruminal methane emissions, and nutrient utilization in lactating cows. Translational Animal Science. 2017;1(3): 277-86.

27. Jaakkola S, Huhtanen P. The effects of forage preservation method and proportion of concentrate on nitrogen digestion and rumen fermentation in cattle. Grass Forage Sci. 1993;48(2): 146-54.

28. Tesfa AT. Effects of rapeseed oil on rumen enzyme activity and in sacco degradation of grass silage. Anim Feed Sci Tech. 1992;36(1-2): 77-89.

29. Zened A, Enjalbert F, Nicot M, Troegeler-Meynadier A. Starch plus sunflower oil addition to the diet of dry dairy cows results in a trans-11 to trans-10 shift of biohydrogenation. J Dairy Sci. 2013;96(1): 4519 .

30. Dewhurst RJ, Davies DR, Merry RJ. Microbial protein supply from the rumen. Anim Feed Sci Tech. 2000;85(1-2): 1-21. 
31. Lechartier C, Peyraud JL. The effects of starch and rapidly degradable dry matter from concentrate on ruminal digestion in dairy cows fed corn silage-based diets with fixed forage proportion. J Dairy Sci. 2011;94(5): 2440-54.

32. Bougouin A, Martin C, Doreau M, Ferlay A. Effects of starch-rich or lipid-supplemented diets that induce milk fat depression on rumen biohydrogenation of fatty acids and methanogenesis in lactating dairy cows. Animal. 2019;13(7): 1421-31.

33. DG P, EA M, DE B. Diet-induced milk fat depression in dairy cows results in increased trans-10, cis-12 CLA in milk fat and coordinate suppression of mRNA abundance for mammary enzymes involved in milk fat synthesis. The Journal of nutrition. 2003;133(10): 3098-102.

34. Allen MS, Bradford BJ, Harvatine KJ. The cow as a model to study food intake regulation. Annu Rev Nutr. 2005;25: 523-47.

35. Harvatine KJ, Allen MS. Effects of fatty acid supplements on ruminal and total tract nutrient digestion in lactating dairy cows. J Dairy Sci. 2006;89(3): 1092-103.

36. Baumgard LH, Matitashvili E, Corl BA, Dwyer DA, Bauman DE. Trans-10, cis-12 conjugated linoleic acid decreases lipogenic rates and expression of genes involved in milk lipid synthesis in dairy cows. $J$ Dairy Sci. 2002;85(9): 2155-63.

37. Harvatine KJ, Allen MS. Effects of fatty acid supplements on feed intake, and feeding and chewing behavior of lactating dairy cows. J Dairy Sci. 2006;89(3): 1104-12.

38. Herrera-Saldana R, Huber JT. Influence of varying protein and starch degradabilities on performance of lactating cows. J Dairy Sci. 1989;72(6): 1477-83.

39. Costa A, Lopez-Villalobos N, Sneddon NW, Shalloo L, Franzoi M, De Marchi M et al. Invited review: Milk lactose-Current status and future challenges in dairy cattle. J Dairy Sci. 2019;102(7): 5883-98.

40. Kim EJ, Sanderson R, Dhanoa MS, Dewhurst RJ. Fatty acid profiles associated with microbial colonization of freshly ingested grass and rumen biohydrogenation. J Dairy Sci. 2005;88(9): 3220-30.

41. Chilliard Y, Glasser F, Ferlay A, Bernard L, Rouel J, Doreau M. Diet, rumen biohydrogenation and nutritional quality of cow and goat milk fat. Eur J Lipid Sci Tech. 2007;109(8): 828-55.

42. Palmquist $D L$, Beaulieu AD, Barbano DM. Feed and animal factors influencing milk fat composition. J Dairy Sci. 1993;76(6): 1753-71.

43. Vlaeminck B, Fievez V, Cabrita A, Fonseca A, Dewhurst RJ. Factors affecting odd-and branchedchain fatty acids in milk: A review. Anim Feed Sci Tech. 2006;131(3): 389-417. 
44. Rego OA, Alves SP, Antunes L, Rosa H, Alfaia C, Prates J et al. Rumen biohydrogenation-derived fatty acids in milk fat from grazing dairy cows supplemented with rapeseed, sunflower, or linseed oils. J Dairy Sci. 2009;92(9): 4530-40.

45. Enjalbert $F$, Videau $Y$, Nicot M, Troegeler Meynadier A. Effects of induced subacute ruminal acidosis on milk fat content and milk fatty acid profile. J Anim Physiol an N. 2008;92(3): 284-91.

46. Jurjanz S, Monteils V, Juaneda P, Laurent F. Variations of trans octadecenoic acid in milk fat induced by feeding different starch-based diets to cows. Lipids. 2004;39(1): 19-24.

47. Boeckaert C, Fievez V, Van Hecke D, Verstraete W, Boon N. Changes in rumen biohydrogenation intermediates and ciliate protozoa diversity after algae supplementation to dairy cattle. Eur J Lipid Sci Tech. 2007;109(8): 767-77.

48. Boeckaert C, Vlaeminck B, Dijkstra J, Issa-Zacharia A, Van Nespen T, Van Straalen W et al. Effect of dietary starch or micro algae supplementation on rumen fermentation and milk fatty acid composition of dairy cows. J Dairy Sci. 2008;91(12): 4714-27.

49. Kairenius P, Ärölä A, Leskinen H, Toivonen V, Ahvenjärvi S, Vanhatalo A et al. Dietary fish oil supplements depress milk fat yield and alter milk fatty acid composition in lactating cows fed grass silage-based diets. J Dairy Sci. 2015;98(8): 5653-71.

50. Butler G. Manipulating dietary PUFA in animal feed: Implications for human health. P Nutr Soc. 2014;73(1): 87-95.

51. Adewuyi AA, Gruys E, Van Eerdenburg F. Non esterified fatty acids (NEFA) in dairy cattle. A review. Vet Quart. 2005;27(3): 117-26.

52. Bell AW. Regulation of organic nutrient metabolism during transition from late pregnancy to early lactation. J Anim Sci. 1995;73(9): 2804-19.

53. Andersson L, Lundström K. Effect of feeding silage with high butyric acid content on ketone body formation and milk yield in postparturient dairy cows. Zentralblatt für Veterinärmedizin Reihe A. 1985;32(1-10): 15-23.

54. Roche JR, Kay JK, Phyn C, Meier S, Lee JM, Burke CR. Dietary structural to nonfiber carbohydrate concentration during the transition period in grazing dairy cows. J Dairy Sci. 2010;93(8): 3671-83.

55. Zhang HB. Effects of dietary supplement soybean oil on lactation performance, blood biochemical index and hormone concentration in early lactation dairy cows. Chinese Journal of Animal Science. 2018;54(09): 89-93.

56. Nousiainen J, Shingfield KJ, Huhtanen P. Evaluation of milk urea nitrogen as a diagnostic of protein feeding. J Dairy Sci. 2004;87(2): 386-98. 
57. Broderick GA, Clayton MK. A statistical evaluation of animal and nutritional factors influencing concentrations of milk urea nitrogen. J Dairy Sci. 1997;80(11): 2964-71.

58. Ramesh B, Karuna R, Sreenivasa RS, Haritha K, Sai MD, Sasis BRB et al. Effect of Commiphora mukul gum resin on hepatic marker enzymes, lipid peroxidation and antioxidants status in pancreas and heart of streptozotocin induced diabetic rats. Asian Pacific journal of tropical biomedicine. 2012;2(11): 895-900.

59. Stojević Z, Piršljin J, Milinković-Tur S, Zdelar-Tuk M, Ljubić BB. Activities of AST, ALT and GGT in clinically healthy dairy cows during lactation and in the dry period. Vet Arhiv. 2005;75(1): 67-73.

60. Sordillo LM, Aitken SL. Impact of oxidative stress on the health and immune function of dairy cattle. Vet Immunol Immunop. 2009;128(1-3): 104-9.

61. Halliwell B, Whiteman M. Measuring reactive species and oxidative damage in vivo and in cell culture: How should you do it and what do the results mean? Brit J Pharmacol. 2004;142(2): 231-55.

62. Ghiselli A, Serafini M, Natella F, Scaccini C. Total antioxidant capacity as a tool to assess redox status: Critical view and experimental data. Free Radical Bio Med. 2000;29(11): 1106-14.

63. Abaker JA, Xu TL, Jin D, Chang GJ, Zhang K, Shen XZ. Lipopolysaccharide derived from the digestive tract provokes oxidative stress in the liver of dairy cows fed a high-grain diet. J Dairy Sci. 2017;100(1): 666-78.

64. Djuric Z, Lewis SM, Lu MH, Mayhugh M, Tang N, Hart RW. Effect of varying dietary fat levels on rat growth and oxidative DNA damage. Nutrition and cancer. 2001;39(2): 214-9.

65. Chen H, Tsai C, Yang J, Liu C, Kuo W, Lii C. The combined effects of garlic oil and fish oil on the hepatic antioxidant and drug-metabolizing enzymes of rats. Brit J Nutr. 2003;89(2): 189-200.

66. Ametaj BN, Zebeli Q, Saleem F, Psychogios N, Lewis MJ, Dunn SM et al. Metabolomics reveals unhealthy alterations in rumen metabolism with increased proportion of cereal grain in the diet of dairy cows. Metabolomics. 2010;6(4): 583-94.

67. Maia MR, Chaudhary LC, Figueres L, Wallace RJ. Metabolism of polyunsaturated fatty acids and their toxicity to the microflora of the rumen. Antonie Van Leeuwenhoek. 2007;91(4): 303-14.

68. Amaretti A, Di Nunzio M, Pompei A, Raimondi S, Rossi M, Bordoni A. Antioxidant properties of potentially probiotic bacteria: In vitro and in vivo activities. Appl Microbiol Biot. 2013;97(2): 809-17.

69. Pi Y, Ma L, Wang H, Wang J, Xu J, Bu D. Rubber seed oil and flaxseed oil supplementation on serum fatty acid profile, oxidation stability of serum and milk, and immune function of dairy cows. Asian Austral J Anim. 2019;32(9): 1363-72. 


\section{Tables}

Table 1. Ingredient and chemical composition of experimental diets 


\begin{tabular}{|c|c|c|}
\hline \multirow[t]{2}{*}{ Item } & \multicolumn{2}{|c|}{ Treatment } \\
\hline & $\mathrm{CON}$ & HSO \\
\hline \multicolumn{3}{|l|}{ Ingredients, $\%$ of DM } \\
\hline Corn silage & 10.7 & 8.1 \\
\hline Oat hay & 7.0 & 5.4 \\
\hline Alfalfa hay & 16.7 & 12.7 \\
\hline High moisture corn & 4.7 & 3.6 \\
\hline Steam-flaked corn & 9.3 & 7.1 \\
\hline Fine ground corn & 9.9 & 27.8 \\
\hline Soybean oil & - & 3.5 \\
\hline DDGS $^{1}$ & 2.8 & 2.1 \\
\hline Soybean meal & 5.0 & 3.8 \\
\hline Canola meal & 5.4 & 4.1 \\
\hline Beet pulp & 6.5 & 5.0 \\
\hline Brewers`grain & 6.9 & 5.2 \\
\hline Pineapple peel & 2.4 & 1.8 \\
\hline Whole cottonseed & 6.9 & 5.3 \\
\hline Canemolasses & 2.5 & 1.9 \\
\hline RumiFat $^{2}$ & 0.8 & 0.6 \\
\hline Mineral-vitamin premix ${ }^{3}$ & 0.46 & 0.35 \\
\hline Calcium hydrogen phosphate & 0.36 & 0.27 \\
\hline Calcium carbonate & 0.72 & 0.55 \\
\hline Sodium bicarbonate & 0.72 & 0.55 \\
\hline Magnesium oxide & 0.13 & 0.10 \\
\hline Salt & 0.36 & 0.27 \\
\hline \multicolumn{3}{|l|}{ Chemical composition, \% of DM } \\
\hline Ash & 7.1 & 5.7 \\
\hline $\mathrm{CP}$ & 16.1 & 14.1 \\
\hline NDF & 31.4 & 26.4 \\
\hline
\end{tabular}

Page 18/24 


\begin{tabular}{|lll|}
\hline ADF & 19.5 & 15.8 \\
\hline Ether extract & 4.6 & 7.8 \\
\hline Starch & 23.8 & 31.4 \\
\hline Forage to concentrate ratio. & $50: 50$ & $62: 38$ \\
\hline FA, g/100g Total FA & & \\
\hline C16:0 & 32.75 & 28.71 \\
\hline C18:0 & 3.40 & 3.20 \\
\hline C18:1n9c & 16.53 & 18.23 \\
\hline C18:2n6c & 43.50 & 46.69 \\
\hline C18:3n3 & 3.81 & 3.13 \\
\hline
\end{tabular}

Note: ${ }^{1}$ Dried distilled grains with soluble. ${ }^{2}$ RumiFat: Prilled hydrogenated palm FA distillate (Ecolex Sdn. Bhd, Malaysia). ${ }^{3}$ Premix/kg (DM basis) contains: $1,100,000$ IU Vitamin A; 360,000 IU Vitamin $D_{3} ; 10,000 \mathrm{mg}$ Vitamin E ; 2,525mg Cu; 4,150mg Fe; 10,025mg Zn; 4,200mg Mg; 60mg Co; $100 \mathrm{mg}$ Se; 200mg I; $16.2 \%$ Mg; 200mg Biotin; 300mg ß-carotene; 3,000mg Monensin.

Table 2. Effect of dietary treatment on rumen $\mathrm{pH}$ and fermentation parameters in dairy cows 


\begin{tabular}{|c|c|c|c|c|}
\hline \multirow[t]{2}{*}{ Item } & \multicolumn{2}{|c|}{ Treatment ${ }^{1}$} & \multirow[t]{2}{*}{ SEM $^{2}$} & \multirow[t]{2}{*}{$P$-value } \\
\hline & CON & HSO & & \\
\hline Mean pH & 6.29 & 6.14 & 0.26 & 0.13 \\
\hline $\mathrm{NH}_{3}-\mathrm{N}, \mathrm{mg} / 100 \mathrm{~mL}$ & 8.69 & 2.96 & 1.06 & $<0.01$ \\
\hline \multicolumn{5}{|c|}{ VFA concentration, mmol/L } \\
\hline Acetate & 47.55 & 41.37 & 14.66 & 0.21 \\
\hline Propionate & 16.47 & 17.15 & 9.85 & 0.84 \\
\hline Isobutyrate & 0.36 & 0.32 & 0.04 & 0.47 \\
\hline Butyrate & 9.33 & 10.13 & 0.88 & 0.47 \\
\hline Isovalerate & 0.75 & 0.88 & 0.15 & 0.56 \\
\hline Valerate & 1.04 & 1.02 & 0.11 & 0.89 \\
\hline Total VFA & 74.31 & 68.88 & 26.21 & 0.54 \\
\hline Acetate: Propionate & 2.83 & 2.39 & 0.19 & 0.13 \\
\hline \multicolumn{5}{|c|}{ mmol/100mmol total VFAs, \% } \\
\hline Acetate & 62.85 & 58.52 & 4.98 & 0.02 \\
\hline Propionate & 22.73 & 25.46 & 7.45 & 0.23 \\
\hline Butyrate & 12.07 & 13.34 & 0.90 & 0.34 \\
\hline
\end{tabular}

Note: ${ }^{1} \mathrm{CON}=$ the cows fed the control diets; $\mathrm{HSO}=$ the cows fed the high-starch and high-oil diets;

${ }^{2}$ Standard error of the mean.

Table 3. Effect of dietary treatment on DMI, milk yield and composition in dairy cows 


\begin{tabular}{|lllll|}
\hline Item & \multicolumn{2}{l}{ Treatment $^{1}$} & SEM $^{2}$ & P-value \\
\cline { 2 - 4 } & CON & HSO & & \\
\hline DMl, kg/d & 20.54 & 19.12 & 0.70 & 0.01 \\
\hline Milk, kg/d & 29.36 & 25.89 & 2.62 & $<0.01$ \\
\hline FCM(3.5\% fat) ${ }^{3}, \mathrm{~kg} / \mathrm{d}$ & 32.41 & 24.26 & 2.65 & $<0.01$ \\
\hline ECM $^{4}, \mathrm{~kg} / \mathrm{d}$ & 29.82 & 23.2 & 2.39 & $<0.01$ \\
\hline Milk fat,\% & 4.07 & 2.87 & 0.10 & $<0.01$ \\
\hline Milk protein,\% & 3.44 & 3.67 & 0.08 & $<0.01$ \\
\hline Milk Lactose,\% & 4.98 & 5.33 & 0.12 & $<0.01$ \\
\hline SNF ${ }^{5} \%$ & 9.26 & 9.82 & 0.47 & $<0.01$ \\
\hline Milk fat, kg/d & 1.23 & 0.82 & 0.10 & $<0.01$ \\
\hline Milk protein, kg/d & 1.0 & 0.93 & 0.10 & 0.04 \\
\hline Milk Lactose, kg/d & 1.44 & 1.35 & 0.12 & 0.05 \\
\hline SNF, kg/d & 2.69 & 2.49 & 0.22 & 0.03 \\
\hline FCM/DMI & 1.62 & 1.30 & 0.14 & $<0.01$ \\
\hline
\end{tabular}

Note: ${ }^{1} \mathrm{CON}=$ the cows fed the control diets; $\mathrm{HSO}=$ the cows fed the high-starch and high-oil diets;

${ }^{2}$ Standard error of the mean; ${ }^{3} 3.5 \%$-fat-corrected milk $(\mathrm{kg})=(0.4318 \times$ Milk yield $)+(16.23 \times$ Milk fat yield $) ;{ }^{4}$ Energy-corrected milk $=(0.327 \times$ Milk yield $(\mathrm{kg} / \mathrm{d}))+(12.95 \times$ Milk fat yield $(\mathrm{kg} / \mathrm{d}))+(7.2 \times$ Milk protein yield $(\mathrm{kg} / \mathrm{d})) ;{ }^{5}$ solid of non-fat.

Table 4. Effect of dietary treatments on milk fatty acid (FA) profiles $[\mathrm{g} / 100 \mathrm{~g}$ total $\mathrm{FA}]$ in dairy cows 


\begin{tabular}{|c|c|c|c|c|}
\hline \multirow[t]{2}{*}{ Item } & \multicolumn{2}{|c|}{ Treatment $^{1}$} & \multirow[t]{2}{*}{ SEM $^{2}$} & \multirow[t]{2}{*}{$P$-value } \\
\hline & CON & HSO & & \\
\hline C6:0 & 4.60 & 5.65 & 0.53 & 0.12 \\
\hline C8:0 & 1.05 & 0.49 & 0.11 & $<0.01$ \\
\hline C10:0 & 2.82 & 1.38 & 0.23 & $<0.01$ \\
\hline $\mathrm{C} 11: 0$ & 0.28 & 0.00 & 0.03 & $<0.01$ \\
\hline C12:0 & 3.16 & 1.68 & 0.16 & $<0.01$ \\
\hline C14:0 & 10.80 & 8.26 & 0.37 & $<0.01$ \\
\hline C14:1 & 0.84 & 1.11 & 0.13 & 0.03 \\
\hline C15:0 & 1.04 & 0.74 & 0.05 & $<0.01$ \\
\hline $\mathrm{C} 16: 0$ & 33.53 & 28.09 & 0.84 & $<0.01$ \\
\hline C16:1 & 1.69 & 2.36 & 0.24 & 0.04 \\
\hline $\mathrm{C} 17: 0$ & 0.47 & 0.30 & 0.03 & $<0.01$ \\
\hline C18:0 & 10.14 & 8.21 & 0.52 & 0.02 \\
\hline C18:1n9t & 2.03 & 12.93 & 0.39 & $<0.01$ \\
\hline C18:1n9c & 21.07 & 21.82 & 0.75 & 0.47 \\
\hline C18:2n6t & 0.23 & 0.49 & 0.52 & $<0.01$ \\
\hline C18:2n6c & 3.01 & 3.26 & 0.11 & 0.02 \\
\hline C18:3n3 & 0.44 & 0.80 & 0.07 & 0.01 \\
\hline Unidentified & 2.80 & 2.43 & 0.20 & 0.15 \\
\hline $\mathrm{FA}<\mathrm{C} 16^{3}$ & 24.56 & 18.73 & 1.32 & 0.01 \\
\hline $\mathrm{C} 16: 0+\mathrm{C} 16: 1^{4}$ & 35.22 & 30.45 & 1.00 & $<0.01$ \\
\hline $\mathrm{FA}>\mathrm{C} 16^{5}$ & 37.38 & 48.29 & 0.88 & $<0.01$ \\
\hline Total saturates FA & 67.86 & 54.22 & 0.93 & $<0.01$ \\
\hline Total unsaturated FA & 29.30 & 43.25 & 1.06 & $<0.01$ \\
\hline Total mono-unsaturated FA & 25.62 & 38.40 & 1.08 & $<0.01$ \\
\hline Total poly-unsaturated FA & 3.68 & 4.85 & 0.21 & $<0.01$ \\
\hline Medium chain FA & 12.99 & 8.61 & 0.90 & 0.01 \\
\hline Long chain FA & 84.08 & 88.86 & 0.95 & 0.01 \\
\hline
\end{tabular}




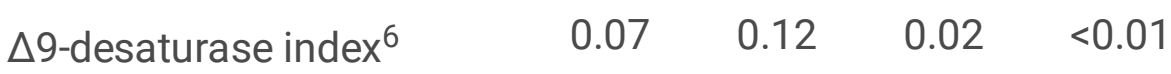

Note: ${ }^{1} \mathrm{CON}=$ the cows fed the control diets; $\mathrm{HSO}=$ the cows fed the high-starch and high-oil diets;

${ }^{2}$ Standard error of the mean; ${ }^{3}$ Originated from de novo synthesis, ${ }^{4}$ Result of both de novo and preformed sources; ${ }^{5}$ Preformed FA taken up by the mammary gland; ${ }^{6}$ Calculated as $\mathrm{C} 14: 1 /(\mathrm{C} 14: 0+$ C14:1).

Table 5. Effect of dietary treatments on plasma metabolites profiles in dairy cows

\begin{tabular}{|c|c|c|c|c|}
\hline \multirow[t]{2}{*}{ Item } & \multicolumn{2}{|c|}{ Treatment $^{1}$} & \multirow[t]{2}{*}{ SEM $^{2}$} & \multirow[t]{2}{*}{$P$-value } \\
\hline & CON & HSO & & \\
\hline $\mathrm{BHBA}^{3}, \mathrm{mmol} / \mathrm{L}$ & 0.60 & 0.48 & 0.03 & 0.05 \\
\hline $\mathrm{NEFA}^{4}, \mathrm{mmol} / \mathrm{L}$ & 0.06 & 0.13 & 0.01 & $<0.01$ \\
\hline Glucose, mmol/L & 3.92 & 4.04 & 0.10 & 0.34 \\
\hline $\mathrm{TC}^{5}, \mathrm{mmol} / \mathrm{L}$ & 7.16 & 6.71 & 0.36 & 0.17 \\
\hline $\mathrm{TG}^{6}, \mathrm{mmol} / \mathrm{L}$ & 0.04 & 0.05 & 0.02 & 0.58 \\
\hline Insulin, ulU/mL & 25.77 & 27.32 & 3.03 & 0.71 \\
\hline $\mathrm{BUN}^{7}, \mathrm{mmol} / \mathrm{L}$ & 4.67 & 3.00 & 0.21 & $<0.01$ \\
\hline$A L T^{8} ه \mathrm{U} / \mathrm{L}$ & 29.36 & 23.49 & 1.12 & $<0.01$ \\
\hline $\mathrm{AST}^{9}{ }^{\otimes U} / \mathrm{L}$ & 80.16 & 105.59 & 7.54 & $<0.01$ \\
\hline $\operatorname{ALP}^{10} \varangle \mathrm{U} / \mathrm{L}$ & 67.44 & 77.85 & 3.62 & 0.06 \\
\hline $\mathrm{TP} P^{11} \rrbracket g / L$ & 73.98 & 73.51 & 1.19 & 0.73 \\
\hline$A_{L B}{ }^{12} \rrbracket g / L$ & 37.14 & 35.26 & 0.43 & 0.02 \\
\hline $\mathrm{GLB}^{13} \bowtie \mathrm{g} / \mathrm{L}$ & 37.26 & 38.25 & 1.02 & 0.36 \\
\hline ALB/GLB & 0.99 & 0.95 & 0.02 & 0.02 \\
\hline
\end{tabular}

Note: ${ }^{1} \mathrm{CON}=$ the cows fed the control diets; $\mathrm{HSO}=$ the cows fed the high-starch and high-oil diets;

${ }^{2}$ Standard error of the mean; ${ }^{3} \beta$-Hydroxybutyric acid; ${ }^{4}$ nonesterified fatty acid; ${ }^{5}$ total cholesterol; ${ }^{6}$ triglyceride; 
${ }^{7}$ urea nitrogen; ${ }^{8}$ alanine aminotransferase; ${ }^{9}$ aspartate aminotransferase; ${ }^{10}$ alkaline phosphatase; ${ }^{11}$ total protein;

${ }^{12}$ albumin; ${ }^{13}$ globulin.

Table 6. Effect of dietary treatments on plasma oxidative stress biomarkers in dairy cows

\begin{tabular}{|c|c|c|c|c|}
\hline \multirow[t]{2}{*}{ Item } & \multicolumn{2}{|c|}{ Treatment ${ }^{1}$} & \multirow[t]{2}{*}{ SEM $^{2}$} & \multirow[t]{2}{*}{$P$-value } \\
\hline & $\mathrm{CON}$ & HSO & & \\
\hline $\mathrm{T}-\mathrm{AOC}{ }^{3}, \mathrm{U} / \mathrm{mL}$ & 0.45 & 0.42 & 0.01 & 0.01 \\
\hline $\mathrm{SOD}^{4}, \mathrm{U} / \mathrm{mL}$ & 92.41 & 86.08 & 1.33 & 0.01 \\
\hline GSH-Px ${ }^{5}, \mathrm{U} / \mathrm{mL}$ & 71.16 & 46.36 & 6.89 & 0.03 \\
\hline $\mathrm{CAT}^{6}, \mathrm{U} / \mathrm{mL}$ & 0.60 & 0.61 & 0.06 & 0.84 \\
\hline $\mathrm{MDA}^{7} \rrbracket \mathrm{nmol} / \mathrm{mL}$ & 2.48 & 3.26 & 0.28 & 0.02 \\
\hline
\end{tabular}

Note: ${ }^{1} \mathrm{CON}=$ the cows fed the control diets; $\mathrm{HSO}=$ the cows fed the high-starch and high-oil diets;

${ }^{2}$ Standard error of the mean; ${ }^{3}$ Total antioxidant capacity; ${ }^{4}$ superoxide dismutase; ${ }^{5}$ glutathione peroxidase;

${ }^{6}$ catalase; ${ }^{7}$ malondialdehyde. 